\title{
Investigating the Role of Balance of Population and Economic Growth in Achieving Sustainable Economic Growth (Case Study: Upper-Middle Income Countries during 1985 to 2016)
}

\author{
Habib Allah Sadeghi ${ }^{1}$ \\ ${ }^{1}$ MA Student in Demography, University of Tehran
}

\begin{tabular}{|c|c|}
\hline ARTICLE INFO & ABSTRACT \\
\hline $\begin{array}{l}\text { Keywords: } \\
\text { Population Growth } \\
\text { Economic Growth } \\
\text { Balance } \\
\text { Birth Rate } \\
\text { Sustainable } \\
\quad \text { Economic } \\
\quad \text { Growth }\end{array}$ & $\begin{array}{l}\text { Contrary to neoclassical view, the population and its components } \\
\text { are one of the factors affecting long-term economic growth. Some } \\
\text { studies have pointed to the negative impact of population growth } \\
\text { and others on its positive impact. The purpose of this paper is to } \\
\text { examine the impact of population growth on economic growth } \\
\text { during } 1985 \text { to } 2007 \text { and } 1985 \text { to } 2016 \text { among the } 32 \text { member } \\
\text { countries of the upper-middle income group. Using World Bank } \\
\text { data (2016) and the panel's method, the impact of population growth } \\
\text { and birth rate on economic growth in two continuous periods has } \\
\text { been investigated. The results show that the more we approach the } \\
\text { present time, the impact of population growth and birth rate on } \\
\text { economic growth in upper-middle income countries decreases; } \\
\text { consequently, if the effect of these two components i.e population } \\
\text { growth and birth rate is not controlled in this group of countries and } \\
\text { countries with lower income, it will be led a negative effect on } \\
\text { economic growth. Therefore, considering this research, the effect of } \\
\text { demographic factors can be shown as long-term; it is important to } \\
\text { note that by declining population growth and birth rate in this group } \\
\text { of countries, investment, productivity of workforce and the } \\
\text { population in age of activity increases. Economic growth reduces } \\
\text { due to the disruption of the balance and the increase in population } \\
\text { on the economic power. By increasing one unit of the population } \\
\text { growth, economic growth has achieved to 0.17\% reduction in } 2016 \\
\text { from } 0.26 \% \text { increase in } 2007 \text {. }\end{array}$ \\
\hline
\end{tabular}

\section{Introduction}

Economic growth, in simple term, is the increase in a country's production in a particular year compared to its amount in base year. At macro level, the increase in gross national product (GNP) or gross domestic product (GDP) in the year under discussion relative to its value in a base year is considered economic growth. The reason that base year prices are used for calculating economic growth is that calculated increase in GDP is due to an increase in output and the impact of price increase (inflation) to be eliminated. If national production rises, it can be said that economic growth has taken place in that country. It is always expected a higher economic growth rate from developing countries and the third world due to high economic capacities (inactive labor and unused land). In a more comprehensive definition of economic growth: the increase in the country's gross domestic product over a given period, Michael Todaro considers economic growth as a sustainable process, that the economic production

* Corresponding author E-mail address: habib.sadeghi@ut.ac.ir 
capacity increases over time due to it and national income level increases. But in the view of Kuznets, economic growth has a more precise concept and it is defined the long-term increase in production capacity in order to supply the most varied economic goods to the people (Mohammad Zadeh, 2002)

The sources of economic growth in the international economy include: increasing production inputs (increasing labor or capital), increasing the productivity of production factors, employing vacant potential capacities in the economy. In order to achieve a sustainable economic growth, we have to follow this debate institutionally. And can increasing labor supply, which is influenced by demographic factors, lead to economic growth? As it is observed from Ricardo's descending theory, rising force in the traditional and agriculture and livestock-based economies will lead to economic growth, but after one step, it will lead to a decline in final production as well as negative economic growth. So besides the apparent aspect, its inherent aspect must be considered.

In relation to the issue of population growth and its implications in economics, research has been carried out with an economic background, which has roughly investigated the population and its components from pernicious-like approach; one of the common theoretical approaches in population economics is the discussion about impact of the population on economic development and that population growth has negative or positive effects for the economic system? In response to this question, three perspectives have been raised in the field of population economics: the "pessimistic perspective of population" that Robert Malthus (1798) and Paul Erlich (1968) have investigated it, which consider population growth as a barrier to economic development and raise it as an issue. In contrast, there is "optimistic perspective of the population" that Bazrab (1965) Kuznets (1967) and Simon (1981) is its main theorists. Not only they not consider population growth an issue, but also they consider it a source of prosperity, wealth, and economic growth. The third perspective that advocates neoclassical growth models, people such as Kelly and Schmitt, have investigated it, they have adopted an "unbiased" position and believe that population growth alone and apart from other factors has little effect on economic growth. (Sadeghi, 2012). But the fourth perspective that presents this paper and, according to its findings, also confirms it is the "hybrid" approach that population growth has positive and negative effects on economic growth in several stages. It emphasizes the role of governments and policymakers in timely control of population growth in order to achieve sustainable economic growth. Finally, the present study investigates the issue of population with a different approach and does not consider it an issue, but it considers it as a two-edged sword that can lead to economic growth and can also reduce economic growth. In order to clarify this issue, we examine the data of four income groups from 1985 to 2016. From these four income groups, the present study investigates the upper-middle income group scientifically. The reason for choosing this group is that Iran is also in this group; one of the goals of this study is to investigate the effect of population growth on Iran's economic growth.

\section{Problem statement and necessity of research}

Today, in order to achieve prosperity and comprehensive development, each country has to predict its needs and facilities in the short, medium and long term, and after the design and implementation of economic and social planning is to meet those needs. In this regard, structure and dynamism of population are considered as the axis of economic and social planning. Hence, the dynamism of the population, which deals with the determinants and consequences of changes in the structure, distribution, and growth of the population, has great research and political importance, because not only it shows the path of the past, but opens the perspective of the future of demographic changes to policymakers and provides a good understanding of the opportunities and challenges of the future. This situation can help policy makers and 
planners to create an environment and a suitable context for exploiting opportunities and coping with challenges. (Sadeghi, 2012)

The world has very different economies; some economies are rich and others are poor. Economic growth in some of these countries is rapid and others do not have growth. Nevertheless, high growth and economic development are among the important goals that economies are seeking. The reason for this is because of the benefits and benefits (such as improving and enhancing living level, reducing poverty and unemployment) that realizes in the process of growth. But achieving a high and sustainable economic growth rate requires answering to the question of what factors determine the rate of economic growth? How economic growth rate is affected by different factors and policies? Including factors that determines the GDP of a country over a year can be: natural resources, human capital, capital goods, and entrepreneurship. One of the issues that relates to this research is the role of human capital, the value that human beings enter the market. The nations that invest in people's health, education and education have a much more valuable labor. Human capital involves the education, skills and health cares of the workers, and the value entered to the economy of the country. Examples include computer / reading / writing / math skills, music / sports / acting talent, ability to follow directions, leadership ability and collaboration with members of the literacy rate group of each country affects human capital in that country. Percentage of population over 15 years' old who can read and write all and all affects, provided that managerial and political backgrounds to be available to use these skills. How does human capital affect economic growth? Nations investing in people's health and education have a much more valuable labor that produces more goods and services. Learned people are more in relation with technological advances, which results in better use of natural resources and produce more commodities. Finally, one of the factors that have always been discussed is the issue of population growth, which is discussed among economists and demographers. Because economists consider population growth as the cause of reducing economic growth and on the contrary, the answer to the question of what effect does population growth have on the economic growth of upper middle-income countries required the need to carry out this research.

\section{Research background}

In this section, Table 1 investigates the studies on the subject of research, which includes both domestic and foreign research.

Table 1: Research background related to research topic

\begin{tabular}{|c|c|c|c|c|}
\hline Authors & Year & $\begin{array}{c}\text { Research } \\
\text { method }\end{array}$ & Subject & Result \\
\hline $\begin{array}{c}\text { Darat and } \\
\text { Elyosuf }\end{array}$ & 1999 & Panel & $\begin{array}{c}\text { Long-term relationship } \\
\text { between population growth } \\
\text { and economic growth }\end{array}$ & $\begin{array}{c}\text { In the stage of development, } \\
\text { population growth leads to economic } \\
\text { growth. }\end{array}$ \\
\hline $\begin{array}{c}\text { Dorick and } \\
\text { Brender }\end{array}$ & 1994 & Panel & $\begin{array}{c}\text { Population growth and fertility } \\
\text { on economic growth }\end{array}$ & $\begin{array}{c}\text { Population growth reduces economic } \\
\text { growth. }\end{array}$ \\
\hline $\begin{array}{c}\text { Bilal } \\
\text { Souvas }\end{array}$ & 2008 & Panel & $\begin{array}{c}\text { Population growth and } \\
\text { economic growth per capita }\end{array}$ & $\begin{array}{c}\text { There is a positive and strong } \\
\text { relationship }\end{array}$ \\
\hline Ellen Kelly & 1995 & Survey & $\begin{array}{c}\text { Correlation between total } \\
\text { population and economic } \\
\text { growth }\end{array}$ & $\begin{array}{c}\text { There is a negative and significant } \\
\text { relationship. }\end{array}$ \\
\hline $\begin{array}{c}\text { Mohrabian } \\
\text { and Sedghi } \\
\text { Sigarchi }\end{array}$ & 1398 & Panel & $\begin{array}{c}\text { Impact of population growth } \\
\text { on economic growth }\end{array}$ & $\begin{array}{c}\text { Confirm positive and negative effects } \\
\text { for different groups }\end{array}$ \\
\hline $\begin{array}{c}\text { Amani and } \\
\text { Hamedani }\end{array}$ & 1994 & Panel & $\begin{array}{c}\text { Interaction of population and } \\
\text { economic development }\end{array}$ & $\begin{array}{c}\text { The population's negative impact on } \\
\text { economic development }\end{array}$ \\
\hline
\end{tabular}




\begin{tabular}{|c|c|c|c|c|}
\hline Sadeghi & 2012 & Panel & $\begin{array}{c}\text { Changes in age structure and } \\
\text { its economic and political } \\
\text { implications }\end{array}$ & $\begin{array}{c}\text { Population growth creates a } \\
\text { population window and, by itself, } \\
\text { cannot lead to economic growth, it } \\
\text { requires appropriate policies. }\end{array}$ \\
\hline Williamson & 2010 & Panel & $\begin{array}{c}\text { Investigating economic } \\
\text { growth in 78 countries }\end{array}$ & $\begin{array}{c}\text { Economic growth in countries with } \\
\text { high active population growth is } \\
\text { higher than in countries where } \\
\text { population growth is lower than the } \\
\text { growth of population at age of } \\
\text { activity. }\end{array}$ \\
\hline
\end{tabular}

\section{Objectives and Hypotheses}

The present research seeks to achieve the following objectives: 1 . The effect of population growth and reproductive growth on fertility in 1985 to 2007, and 1985 to 2016. 2. Determining the difference between the two temporal sections. 3. Determining the pattern of population growth impact on economic growth over time. The research also seeks to make three hypotheses: 1. It seems that there is a relationship between population growth and economic growth. 2. It seems that there is a relationship between fertility rate and economic growth. 3 . It seems that there is a balance between population growth and economic growth.

\section{Research method}

The research method in this research is a research type, the statistical population of the uppermiddle income countries is data used, secondary data obtained from the World Bank, the division of these countries is also done by the World Bank of Information; the sample size and period studied in this study are 32 countries from 156 countries worldwide, which are in the upper-middle income group. Iran by gross per capita GDP of 15090 and a rank of 69 in the world is located in it. The validity and reliability of these data are approved in various researches and organizations responsible for collecting these data. Analysis method in this research is to compare data of population growth and economic growth and their surface analysis, which are extracted using EViews software.

\section{Findings}

The age structure of the population and its relation with economic growth have always been considered to researchers, since studies conducted in population economic field in recent years focused on population dynamics i.e. population growth and its economic implications in the labor market and economic development. However, in recent years, following the miraculous economic transformation of some of the countries of Southeast Asia, the attention of economists and demographers focused on the age structure of the population. The experience of these countries revealed that age structure of the population is also important in economic developments, since different age groups have different economic behaviors. Nevertheless, the theory of neoclassical growth, which is one of the most important views in the study of economic growth and its affecting factors, suggests that the population growth rate is steady and ignores the important issue of population transition. The demographic transition period is a period of demographic changes that the age structure of the population changes due to changes in population growth rates. The importance of the demographic transition period from the late 1980s to economic growth was realized, and the term demographic window or demographic gift was widely used by economic development researchers as well as by demographers. The results of the census 2016 of the Iranian Statistical Center indicate that the age structure of the Iranian population has entered the demographic window since 2006, in which less than one-third of the country's population is placed in the interval of less than 15 and over 65 years. In other words, more than two thirds of the country's population $(71 \%)$ are at work age and can be employed if employment conditions to be provided for them. The share 
of population aged 15-64 will decrease from $69.7 \%$ in 2006 to 63.7 in 2041. This is an indication of the transient of this phenomenon in the Iranian economy.

Predictions show that by 2019, the demand for labor will decline, and obviously, for a good economic growth, the country needs young and efficient labor force. Obviously, if the current trend continues, the country will face the problem of supplying the labor force in the future. They have to use immigrants of European countries to compensate it that it follows its social consequences.

Iran is a country that has many advantages in producing goods. In the field of natural resources, oil and gas and minerals and non-minerals are considered as rich countries. In the field of manpower, according to available statistics, it has a young population that, if properly managed, it can be considered as one of the country's advantages in terms of production and exports. Due to the specific geographic location of Iran and locating in east-west path, and relation with the sea from the north and south, it has created one of the best strategic locations especially for exports (Farhadi, 2004)

Perhaps the most important economic debate in the years after World War II, especially in developing countries, was the issue of economic growth. Hence, many theories were raised about the issue of growth during the years after World War II. The basic aim of growth theories is to explain the determinants of growth rates in a country and to examine the reasons for the difference in growth rates and per capita income between countries. One of the factors that has a significant impact on the economic growth of some developing countries is population growth, which is generally on the path of economic growth.

According to macroeconomic indicators of Iran, the average rate of economic growth during 1992-1992 was 3.9 percent. The continuation of such a process will not create favorable conditions to increase the level of economic prosperity and will keep Iran's economy in the rank of developing countries with low per capita income. Access to high economic levels involves having a realistic analysis of the country's economy and a better understanding of the principles and rules that affect economic growth. There are many factors that directly and indirectly increase economic growth in developed and developing countries. One of these factors, which have a demographic aspect, is the impact of population growth.

\section{Experimental estimation of model}

In this section, the following formulas are used to examine the relationship between population growth and fertility rate with economic growth; they examine the data experimentally. The research conducted in the framework of these formulas is based on the Cook and Scheid (2003) model, which they also adopted this research method from Baror (2001).

1. LOG $($ RGDP) $=$ F $($ LOG $($ POP $)$, LOG $(\mathrm{KI})$, LOG $($ WOK $)$, LOG $($ WPOP $)$

2. $\mathrm{LOG}(\mathrm{RGDP})=\mathrm{h}(\mathrm{Br})$

In the formulas above:

RGDP: Gross Domestic Product

Pop: population

Br: Birth rate

KI: Investment

WPOP: Population at work age

WOK: productivity of workforce

L: Logarithm

As it can be seen, in Formula (1), the relationship between population growth, population growth at work age, growth of productivity of manpower, investment growth and per capita gross product growth are as the operating symbols of economic growth which are investigated in this research. Formula (2) will also examine the relationship between birth rate and GDP per capita growth directly. 


\section{Model estimation method}

The data used for a group has been used over time, which is a feature of panel methods. Finally, we use the formulas 1 and 2 for this group with upper-middle income. And since we are delaying the determination of the right and proper model among the constant effect models and the random effect, we use the Hausman test using Eviews software. Finally, the prier model is the model of constant effect that has been used. The Hausman test formula is as follows:

$\mathrm{H}_{0}: \mathrm{E}\left(\mathrm{u}_{\mathrm{it}} / \mathrm{x}_{\mathrm{it}}\right)=0$

\section{$\mathrm{H}_{1}: \mathrm{E}\left(\mathrm{u}_{\mathrm{it}} / \mathrm{x}_{\mathrm{it}}\right) \neq 0$}

The impact of population growth on economic Growth in upper middle income countries: In this section, the study of the effect of population growth on economic growth in the group of the upper-middle incomes will be reviewed during 1985 to 2007 and also from 1985 to 2016. The results of estimating formula (1) are presented in the following tables.

Table 2: The impact of population growth on economic growth for the upper middle income group during 1985-2007

\begin{tabular}{|c|c|c|c|c|c|c|c|}
\hline R2 & D.W & AR(1) & LOG(WPOP) & LOG(WOK) & LOG(Ki(-1)) & LOG(POP) & $\begin{array}{c}\text { Grouping } \\
\text { countries }\end{array}$ \\
\hline $0 / 99$ & $2 / 2$ & $0 / 90$ & $0 / 34$ & $0 / 94$ & $0 / 006$ & $0 / 26$ & $\begin{array}{c}\text { Upper middle } \\
\text { income group }\end{array}$ \\
\hline-- & -- & $59 / 85$ & 3.59 & 67.31 & 1.79 & $2 / 27$ & T- static \\
\hline
\end{tabular}

Source: Mehrabian and Sedghi Sigarchi, 2010

The results of Table (2) show that in countries with upper middle income, $1 \%$ increase in population growth leads to $0.26 \%$ economic growth; in relation to other components, it can be said that for one-unit increase in investment, $0.006 \%$ economic growth increases, for one percent increase of labor productivity, $0.94 \%$ economic growth increases, and finally, by increasing one percent population at work age, $0.34 \%$ economic growth increases. It should be noted that the estimated variables are statistically significant at approximately 5\% and $10 \%$ confidence levels; a significant level of $0.99 \%$ indicates the high power of explaining the estimated models, which is the same for the other tables.

Table 3: The impact of population growth on economic growth for the upper middle income group during 1985 and 2016

\begin{tabular}{|c|c|c|c|c|c|c|c|}
\hline R2 & D.W & AR(1) & LOG(WPOP) & LOG(WOK) & LOG(Ki(-1)) & LOG(POP) & $\begin{array}{c}\text { Grouping } \\
\text { countries }\end{array}$ \\
\hline $0 / 98$ & $2 / 0$ & $0 / 92$ & $0 / 40$ & $0 / 97$ & $0 / 008$ & 0.17 & $\begin{array}{c}\text { Upper middle } \\
\text { income group }\end{array}$ \\
\hline-- & -- & $79 / 31$ & $4 / 05$ & 74.25 & 1.94 & 5 & T- static \\
\hline
\end{tabular}

Source, results of research

The results of Table (3) show that in countries with upper middle income, $1 \%$ increase in population growth leads to $0.17 \%$ economic growth; in relation to other components, it can be said that for one-unit increase in investment, $0.008 \%$ economic growth increases, for one percent increase of labor productivity, $0.97 \%$ economic growth increases, and finally, by increasing one percent population at work age, $0.40 \%$ economic growth increases. It is noteworthy to observe the difference between the 1985 and 2007 period and the 1985 to 2016 period, after nine years, the impact of population growth has been reversed and population growth caused to reduce economic growth from 0.26 to 0.17 percent. This indicates an increase in the population of this group with upper-middle income, which the size of the population has 
become more than economic power, and the economy of these countries does not have the ability to boost their economic growth. The main point of this discussion, as described in the "step-by-step" view, is that at the beginning of the development, population growth led to an increase in economic growth, but after passing the transitional phase and reaching a moderate level of development, this impact will be negative, although it will take a long time to reach the negative growth (so that economic growth is negative, if demographic policies are not applied), that an increase in population growth will lead to a decline in the economic growth of these countries.

\section{Impact of birth rate on economic growth in upper middle income countries:}

In this section of the study, the effect of population growth on economic growth in the group with upper middle income over the years 1985 to 2007 and also between 1985 and 2016 will be investigated. The results of estimating formulas (2) are presented in the following tables.

Table 4: Impact of birth rate on economic growth for the upper middle income group in 1985-2007

\begin{tabular}{|c|c|c|c|}
\hline R2 & D.W & Br & Grouping countries \\
\hline $0 / 98$ & $2 / 0$ & $0 / 2$ & Upper middle income group \\
\hline-- & -- & $6 / 17$ & T- static \\
\hline
\end{tabular}

Source: Mehrabian and Sedghi Sigarchi, 2010

The results of Table 4 show that in countries with upper middle income, $1 \%$ increase in birth rate creates $0.2 \%$ of economic growth, that with a significant level of 0.98 and a T-value of 6.17 , this relationship is significant and confirmed.

Table 5: Impact of Birth Rate on Economic Growth for the Upper Middle Income Group during 1985 to 2016

\begin{tabular}{|c|c|c|c|}
\hline R2 & D.W & Br & Grouping countries \\
\hline $0 / 99$ & 1.71 & $0 / 1$ & Upper middle income group \\
\hline-- & -- & $16 / 07$ & T- static \\
\hline
\end{tabular}

References: Research results

The results of Table (5) show that in countries with upper middle income, $1 \%$ increase in birth rate creates $0.1 \%$ of economic growth that with a significant level of 0.99 and a T-value of 6.07 , this relationship is significant and confirmed. The important point is a $0.1 \%$ decrease in the birth rate in economic growth after 9 years.

\section{Discussion and conclusion}

The most important economic debate in the years after World War II, especially in developing countries, has been the issue of economic growth. Hence, many theories were raised about the issue of growth during the years after World War II. In this regard, the present research has studied the role of demographic factors and demographic components in influencing economic growth. The research questioned the neoclassical theory and showed that demographic variables played a decisive role in the growth and decline of economic growth and rejected two optimistic and pessimistic perspectives about population growth and economic growth and showed that with the combination of these two perspectives, it can be answered to this issue theoretically. The results of this study indicate that population growth and birth rate as components of population have affected economic growth. The valuable results of this research can be referred to the reduction of the role of demographic components during 2007 to 2016 . The extracted model of this study will be in the form of a hunch, which means that at first, population growth has a very strong impact on economic growth, but after the transition from 
the developmental stage, the impact of economic growth is reduced and even in some societies, it decreases economic growth. In high-income countries, due to the balance between population growth and economic growth, a slight increase in population growth is disruptive of this balance and leads to a decline in economic growth. Positive and high economic growth in these countries is due to two reasons: 1. Economic power that has the ability to grow. 2. The continuous and small population growth is in balance with economic power. The results of this research are contradictory to the results of the research of Amani and Hamedani (1994), Durik and Brander (1994), Kelly and Ettal (1995), and Dacosta and Carroll, as well as consistent with the research of Darat and Eliosof (1999), Bilal Souvas (2008), Mehrabian and Sedghi Sigarchi (2010), Sadeghi (2012) and Williamson (2010). Finally, the present study, by rejecting the three above-mentioned perspectives, was able to reach a new perspective and show the role of demographic variables in economic growth over time; in the end, it presents "Hybrid Perspective". And in the context of this perspective, you will respond to the effects of population growth on economic growth.

The present study was able to examine the role of demographic components in upper middleincome countries, which presents these policy and economic proposals; policymakers should strive to balance between the population growth and economic growth and by timely control of population growth and birth rate helps to the more economic growth of country, but economists must also apply their effort to use the current state of the country i.e the demographic window state (where $70 \%$ of the country's population is in age of activity) and increase economic growth in the country.

\section{References}

Al. Yousif. Y. K and Darrot. A.f. (1995). The long Relationship between population and economic growth: some time series evidence for developing countries. Holy cross web diretory.

Brander. A , James and Dowrick Steve. (1994). The role of fertility and population in economic growth emprical results from aggregate cross national data. Journal of population economics. Springer-verlag.

Farhadi, Alireza, 2004, Investigating Foreign Trade Effects on Iran's Economic Growth, Journal of Program and Budget, Volume 9, Issue 1.

Hamedani, Amani and Hossein, Mohammad, 1994, Effects of Population Growth on Economic Development, Master's Thesis, Imam Sadiq University, School of Islamic Teachings.

Kelly ,Allen and c.Schmidt,Robert M.(1995). Aggregate Population And Economic Growth Population. The Role of the Components of Demographic Change1995.

Mehrabian, Azadeh and Sedghi Sigarchi, Nazila, 2009, The Impact of Population Growth on Economic Growth in the Countries of Four Income Groups Between 1985 and 2007, Economics Quarterly, Fourth Edition, No. 13, Winter 2010

Mohammadzadeh Asl, Nazi, 2002, Neoclassical Economic Growth Theory Test, Economic Research, No. 14

Sadeghi Rasul, 2012, Changes in the Age Structure and Advent of Populations Window in Iran: Economic Consequences and Political Requirements, Women's Strategic Studies: Spring 2012- Scientific-Research

Sauas, Bilal. (2008). The relationship between population and economic growth: emprical evidence from the central asian economice. OAKA.PP. 183-161.

Williamson, J, G. Demographic Change, Economic Growth, and Inequality, In N. Birdsall et al. Population Matters, Oxford University Press (2001).

https://data.worldbank.org/ . from 1985 - 2016. 